\title{
Cationic Host Defence Peptides: Multifaceted Role in Immune Modulation and Inflammation
}

\author{
Ka-Yee Choi Leola N.Y. Chow Neeloffer Mookherjee \\ Manitoba Centre for Proteomics and Systems Biology, Departments of Internal Medicine and Immunology, \\ University of Manitoba, Winnipeg, Man., Canada
}

\section{Key Words}

Inflammation · Host defence peptides - Antimicrobial

peptides $\cdot$ Host defence $\cdot$ Immunomodulation

\begin{abstract}
Host defence peptides (HDPs) are innate immune effector molecules found in diverse species. HDPs exhibit a wide range of functions ranging from direct antimicrobial properties to immunomodulatory effects. Research in the last decade has demonstrated that HDPs are critical effectors of both innate and adaptive immunity. Various studies have hypothesized that the antimicrobial property of certain HDPs may be largely due to their immunomodulatory functions. Mechanistic studies revealed that the role of HDPs in immunity is very complex and involves various receptors, signalling pathways and transcription factors. This review will focus on the multiple functions of HDPs in immunity and inflammation, with special reference to cathelicidins, e.g. LL-37, certain defensins and novel synthetic innate defence regulator peptides. We also discuss emerging concepts of specific HDPs in immune-mediated inflammatory diseases, including the potential use of cationic peptides as therapeutics for immune-mediated inflammatory disorders.
\end{abstract}

Copyright $\odot 2012$ S. Karger AG, Basel

\section{KARGER}

Fax +41613061234

E-Mail karger@karger.ch

www.karger.com
(C) 2012 S. Karger AG, Basel

1662-811X/12/0044-0361\$38.00/0

Accessible online at:

www.karger.com/jin

\section{Introduction}

Antimicrobial peptides were described more than 25 years ago. The peptides cecropins were isolated from the pupae of the moth Hyalophora cecropia in 1980, followed by the discovery of magainins from the skin of the African clawed frog (Xenopus laevis) and defensins from mammalian neutrophils [1]. Cationic antimicrobial peptides have been described in a wide variety of species including plants, insects, amphibians and mammals [2]. Research has predominantly been focused on the structures, functions and potential uses of these peptides as 'alternate' antibiotic-like therapeutics against infections. Various models are proposed for the microbicidal activities of antimicrobial cationic peptides, which include interaction with the negatively charged membrane components of microbes resulting in pore formation, induction of non-specific membrane permeabilization, binding to intracellular targets and disruption of bacterial biofilms $[3,4]$. Natural cationic antimicrobial peptides can indeed protect against a wide range of infections, including bacterial, viral and parasitic [5-8]. However, it is now appre-

K.-Y.C. and L.N.Y.C. contributed equally to this paper. 
Table 1. Examples of immunomodulatory functions of HDPs and IDR peptides

\begin{tabular}{|c|c|c|}
\hline Biological function & Peptide & $\begin{array}{l}\text { Ref. } \\
\text { No. }\end{array}$ \\
\hline $\begin{array}{l}\text { Direct chemotaxis of cell types such as } \\
\text { neutrophils, monocytes, DCs, T cells } \\
\text { and eosinophils }\end{array}$ & $\begin{array}{l}\text { LL-37, PR-39, HNP-1, } \\
\text { HNP-2, hBD-1 and } \\
\text { hBD-2 }\end{array}$ & $\begin{array}{l}52 \\
53 \\
54 \\
55 \\
56\end{array}$ \\
\hline 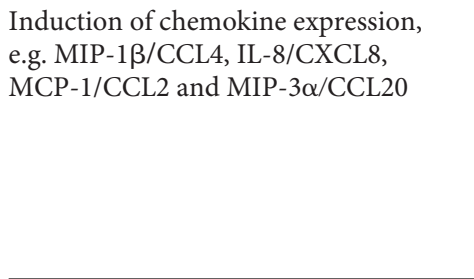 & $\begin{array}{l}\text { LL-37, hBD-2, hBD-3, } \\
\text { IDR-1 and IDR-1002 }\end{array}$ & $\begin{array}{l}57 \\
58 \\
11 \\
40 \\
10 \\
59 \\
15 \\
22\end{array}$ \\
\hline $\begin{array}{l}\text { Regulation of chemokine receptor } \\
\text { expression, e.g. IL-8RB and CXCR } 4\end{array}$ & LL-37 & 22 \\
\hline Suppression of neutrophil apoptosis & LL-37 and hBD-3 & $\begin{array}{l}60 \\
24\end{array}$ \\
\hline $\begin{array}{l}\text { Induction of anti-inflammatory } \\
\text { cytokines, e.g. IL-10 and IL-1RA }\end{array}$ & $\begin{array}{l}\text { LL-37, IDR-1 and } \\
\text { IDR-1002 }\end{array}$ & $\begin{array}{l}20 \\
35 \\
10 \\
22\end{array}$ \\
\hline $\begin{array}{l}\text { Suppression of pro-inflammatory } \\
\text { mediators, e.g. TNF- } \alpha \text {, IL- } 1 \beta \text {, IL- } 6 \text {, } \\
\text { MIP- } 1 \alpha \text { and nitric oxide }\end{array}$ & $\begin{array}{l}\text { LL-37, IDR-1 and } \\
\text { IDR-1002 }\end{array}$ & $\begin{array}{l}20 \\
10 \\
15 \\
22\end{array}$ \\
\hline $\begin{array}{l}\text { Activation of ERK } 1 / 2 \text { and p } 38 \text { MAPK } \\
\text { signalling pathways }\end{array}$ & LL-37 and hBD-2 & $\begin{array}{l}61 \\
40 \\
62 \\
63\end{array}$ \\
\hline $\begin{array}{l}\text { Modification of DC differentiation, } \\
\text { endocytic capacity, phagocytic receptor } \\
\text { expression and cytokine secretion }\end{array}$ & LL-37 and HNP-1-3 & $\begin{array}{l}28 \\
27 \\
25 \\
26\end{array}$ \\
\hline Enhancement of phagocytosis & HNP-1-3 & 64 \\
\hline Induction of autophagy & LL-37 & 18 \\
\hline Promotion of wound/vascular healing & $\begin{array}{l}\text { LL-37, HNP-1, hBD-2 and } \\
\text { hBD-3 }\end{array}$ & $\begin{array}{l}65 \\
66\end{array}$ \\
\hline $\begin{array}{l}\text { Regulation of angiogenesis and } \\
\text { arteriogenesis }\end{array}$ & LL-37 and PR-39 & $\begin{array}{l}67 \\
68\end{array}$ \\
\hline $\begin{array}{l}\text { Activation and degranulation of mast } \\
\text { cells }\end{array}$ & LL-37 and hBD-2-4 & $\begin{array}{l}61 \\
69\end{array}$ \\
\hline $\begin{array}{l}\text { Regulation of } \mathrm{T} \text { and } \mathrm{B} \text { lymphocyte } \\
\text { response }\end{array}$ & CRAMP & 29 \\
\hline Adjuvant-like functions & $\begin{array}{l}\text { BMAP-28, indolicidin, } \\
\text { bactenecin } 2 \mathrm{~A} \text { and } \\
\text { IDR HH2 }\end{array}$ & $\begin{array}{l}70 \\
71 \\
72\end{array}$ \\
\hline $\begin{array}{l}\text { Protection against immune-mediated } \\
\text { inflammation in synovial fibroblasts }\end{array}$ & IDR-1002 & 20 \\
\hline $\begin{array}{l}\text { Protection against inflammatory shock } \\
\text { or sepsis in vivo }\end{array}$ & LL-37 & $\begin{array}{l}73 \\
22\end{array}$ \\
\hline
\end{tabular}

ciated that the direct microbicidal activity of certain cationic antimicrobial peptides, e.g. human LL-37 and human $\beta$-defensin (hBD)-2, is antagonized in the presence of physiological salt concentrations and in the presence of anionic polysaccharides [6,9]. Moreover, two recent studies have conclusively shown that synthetic cationic peptides (based conceptually on natural antimicrobial cationic peptides) with no direct microbicidal properties can protect against various infections in vivo [10, 11]. Consistent with this, various studies, primarily in the last decade, have demonstrated that several cationic antimicrobial peptides have multifunctional roles as immune effector molecules, provide a link between innate and adaptive immunity, contribute to resolution of inflammation, maintain homeostasis and aid in wound healing [reviewed in 1, 12-14] (table 1). Thus, it is likely that the antimicrobial functions of cationic peptides are largely due to their role in host immunity $[5,6,15]$. Therefore, the term host defence peptide (HDP) is currently used for natural cationic peptides, which takes into account their overall biological functions both as antimicrobial and immunomodulatory compounds.

HDPs are gene encoded and vary in size, sequence and structure. They are typically $12-50$ amino acids in length with a net positive charge of +2 to +9 and amphipathic with $40-50 \%$ hydrophobic residues [1]. HDPs are expressed both in circulating leukocytes and structural cells such as epithelial cells [16]. The structures of HDPs can be broadly classified as (1) amphipathic $\alpha$-helix (e.g. cathelicidin LL-37), (2) $\beta$-sheet structures with disulphide bonds (e.g. protegrin), (3) extended structures (indolicidin) and (4) loop structures with one disulphide bond (e.g. bactenecin). To date, more than 1,200 HDPs have been described (http://aps.unmc.edu/AP/main. php). Defensins and cathelicidins are the two best characterized groups of HDPs in mammals. These peptides are expressed as larger precursor pre-pro-proteins, the structures of which allow for transcriptional and posttranscriptional regulation for tightly controlled expression [16]. The pre-pro-proteins are proteolytically processed by endogenous proteases to generate biologically active mature HDPs. For example, the sole human cathelicidin is expressed as an $18-\mathrm{kDa}$ pre-pro-protein, hCAP18, which is cleaved by a serine protease to form the biologically active 37 -amino acid, $\alpha$-helical, amphipathic peptide LL-37. Depending on the specific HDP and the cell type, the expression of these peptides can be constitutive or inducible, and their expression is typically induced by pathogens or other inflammatory effectors such as cytokines $[16,17]$. Examples of physiological concentrations 
and sources of certain HDPs are shown in table 2. Recent studies have also demonstrated that metabolites, such as the active metabolite of vitamin D3, can induce the expression of human cathelicidin LL-37 and hBD-4, which in turn contributes to protection against the intracellular pathogen mycobacteria, possibly by aiding in the process of autophagy [18]. Early research with cationic HDPs was focused on their 'direct' antimicrobial activity. Interest in this area was propelled by the potential of developing novel antibiotic-like therapeutics, especially for antibiotic-resistant pathogens. However, research in the last decade has solidified the critical role of HDPs as immune effector molecules for both innate and adaptive immune responses.

In recent years, small synthetic cationic peptides have been designed based on the widely diverse sequences of HDPs used as templates [19]. These novel synthetic cationic peptides are known as innate defence regulator (IDR) peptides and typically exhibit enhanced immunomodulatory activities. IDR peptides described in recent studies (table 3) are essentially linear derivatives of cathelicidins, were selected based on their ability to stimulate chemokine production in human peripheral blood-derived mononuclear cells, were shown to protect against endotoxin and infectious challenge and, in contrast to the natural cathelicidins, exhibit limited cytotoxicities [10, $11,20,21]$. In this review, we will focus on the immunomodulatory and anti-inflammatory role of HDPs defined so far, with emphasis on cathelicidins and novel synthetic IDR peptides, and further discuss the therapeutic potential of these peptides in immune-mediated inflammatory diseases.

\section{Diverse Immunity-Related Biological Effects}

Various studies have demonstrated that HDPs and their synthetic derivatives, IDR peptides, have multifaceted roles in immunity (summarized in table 1). A primary function associated with certain HDPs is in the facilitation of chemotaxis of immune cells. HDPs, e.g. human cathelicidin LL-37 and defensins human neutrophil peptide (HNP)-1, HNP-2, hBD-1 and hBD-2, can either directly or indirectly promote recruitment of different immune cells such as neutrophils, monocytes, immature dendritic cells (iDCs), T lymphocytes, eosinophils and neutrophils to the site of infection. Human cathelicidin LL-37, human $\alpha$-defensins HNP-1 and HNP-2, murine $\beta$-defensins and porcine cathelicidin PR-39 are direct chemoattractants for cell types such as iDCs, neutrophils
Table 2. Examples of normal physiological concentrations of human HDPs

\begin{tabular}{llll}
\hline HDP & Source & $\begin{array}{l}\text { Physiological } \\
\text { concentration }\end{array}$ & $\begin{array}{l}\text { Ref. } \\
\text { No. }\end{array}$ \\
\hline LL-37 & $\begin{array}{l}\text { plasma (circulating levels } \\
\text { in healthy controls) }\end{array}$ & $27.2 \pm 4.9 \mathrm{ng} / \mathrm{ml}$ & 74 \\
LL-37 & $\begin{array}{l}\text { maternal plasma } \\
\text { cord blood }\end{array}$ & $1.74 \mathrm{ng} / \mathrm{ml}$ & 75 \\
& $\begin{array}{l}\text { (from normal delivery) } \\
\text { ne-37 }\end{array}$ & $1.11 \mathrm{ng} / \mathrm{ml}$ & 75 \\
LL-37 & neonatal tracheal aspirate & $1-4 \mathrm{ng} / \mathrm{ml}$ & 76 \\
hBD-2 & neonatal tracheal aspirate & $250-750 \mathrm{pg} / \mathrm{ml}$ & 76 \\
HNP-1-3 & saliva & $1.3 \pm 0.22 \mu \mathrm{mg} / \mathrm{ml}$ & 77 \\
HNP-1-3 & bronchoalveolar fluid & $12.9 \pm 15 \mathrm{ng} / \mathrm{ml}$ & 78 \\
HNP-1-3 & plasma & $323 \pm 173 \mathrm{ng} / \mathrm{ml}$ & 78 \\
\hline
\end{tabular}

Table 3. Sequences of immunomodulatory IDR peptides

\begin{tabular}{lll}
\hline IDR peptide & Sequence & Ref. No. \\
\hline IDR-1 & KSRIVPAIPVSLL-NH 2 & 10 \\
IDR-1002 & VQRWLIVWRIRK-NH & 11 \\
IDR-1018 & VRLIVAVRIWRR-NH & 21 \\
IDR HH-2 & VQLRIRVAVIRA-NH & 79 \\
\hline
\end{tabular}

and T lymphocytes (table 1). Moreover, at low to modest physiological concentrations, HDPs such as LL-37, hBD-2 and hBD-3 can promote chemotaxis of immune cells indirectly by inducing the production of chemokines such as MCP-1/CCL2, MIP-1ß/CCL4, RANTES/CCL5, MIP$3 \alpha /$ CCL20, Gro- $\alpha /$ CXCL1 and IL-8/CXCL8 from both immune cells and structural cells such as epithelial cells and gingival fibroblasts (table 1). Similarly, synthetic derivatives, i.e. IDR-1 and IDR-1002, can also induce chemokine production $[10,11]$. Induction of chemokines by IDR peptides appears to be cell type dependent; for example, IDR-1002 can induce the production of chemokines from immune cells such as macrophages but not from stromal synovial fibroblasts $[11,20]$. In addition, HDPs such as LL-37 can up-regulate the expression of chemokine receptors such as IL-8RB, CXCR4 and CCR2 in macrophages [22]. Human defensins hBD-1 and hBD2 chemoattract dendritic cells (DCs) and T lymphocytes via the chemokine receptor CCR6, which is preferentially expressed on iDCs and memory $\mathrm{T}$ cells [23]. Thus, it can be summarized that a critical innate immune function of certain HDPs and IDR peptides is the promotion of immune cell recruitment to the site of infection, which 
directly contributes to the clearance of infections. Another innate immune mechanism by which HDPs can protect against bacterial invasion is by prolonging the life span of neutrophils. It has been demonstrated that cathelicidin LL-37 and human defensin hBD-3 suppress neutrophil apoptosis (table 1). LL-37 induces the expression of the anti-apoptotic protein BcL-XL and inhibits caspase-3 activity to suppress neutrophil apoptosis [24]. As neutrophils phagocytose and destroy infectious agents, suppressing apoptosis of neutrophils would aid in host defence mechanisms for resolution of bacterial infections.

Apart from innate immune effector functions, HDPs serve as an important link between the innate and adaptive immune systems. Human HDP LL-37 is a potent modifier of DC differentiation from circulating hematopoietic precursor cells and pre-DCs (monocytes and plasmacytoid cells) and can influence adaptive immunity by interaction with iDCs $[25,26]$. LL-37 up-regulates the endocytic capacity of iDCs, modifies the expression of phagocytic receptors and enhances the secretion of Th1inducing cytokines in mature DCs [26]. Similarly, defensins, e.g. human hBD-3 and HNP-1 to -3 , can initiate the maturation of DCs, up-regulate the expression of costimulatory molecules and activate professional antigenpresenting cells $[27,28]$. Interestingly, it has been demonstrated that effects on DCs mediated by the defensins HNP-1 to -3 are typically observed with low concentrations of defensins that do not have direct antimicrobial activity [28]. This observation also aligns with the recent paradigm that the anti-infective mechanism mediated by some HDPs is largely due to the modulation of host immunity. As iDCs can be activated by innate immune mediators and function as antigen-presenting cells to subsequently activate subsets of $\mathrm{T}$ and $\mathrm{B}$ lymphocytes for the development of the adaptive immune response, it may be proposed that one of the anti-infective mechanisms of HDPs is to influence the differentiation and subsequent change in DC phenotype to promote a robust adaptive immune response. Apart from influencing antigen-presenting cells for the initiation and polarization of adaptive immunity, certain HDPs were shown to have direct effects on lymphocytes. A recent study has demonstrated that the murine cathelicidin CRAMP can directly alter T and $\mathrm{B}$ cell responses and plays a role in regulating adaptive immune responses [29]. Similarly, human defensins HNP-1 to -3 can enhance the proliferation and cytokine responses of $\mathrm{CD} 4+\mathrm{T}$ lymphoctyes from murine spleen and Peyer's patches [30]. The ability of HDPs to influence adaptive immunity is further supported by studies that show that the HDPs BMAP-28 and indolicidin and IDR peptides such as $\mathrm{HH}-2$ have the potential to enhance production of antigen-specific serum antibodies, thus demonstrating adjuvant-like properties (table 1). HDPs are known to promote several other immune-related functions, which include promotion of wound healing, angiogenesis (capillary growth) and arteriogenesis (growth of pre-existing vessels), induction of mast cell degranulation and release of histamine and prostaglandin $\mathrm{D}_{2}$ (see table 1 for specific examples). Unfortunately, the relationship between the structures of the various HDPs and how this relates to the diverse immunity-related functions mediated by these endogenous peptides is not yet resolved.

Research in the last decade has demonstrated direct effects of cationic peptides on immune cells such as macrophages, DCs and T cells, as well as on structural cells, e.g. epithelial cells. These peptides influence both innate and adaptive immune functions. The paradox associated with HDP-mediated immune functions is that even though these peptides promote innate immune effector mechanisms which include certain 'classical' inflammatory responses required for resolution of infections, they also contribute to the resolution of inflammation, thus protecting against the detrimental effect of excessive inflammation (discussed below). Overall, direct effects of HDPs on immune functions contribute to a wide range of biological effects from infection control to wound healing and maintaining homeostasis.

\section{Modulation of Inflammation}

Several in vivo models of infections and sepsis have shown that HDPs such as cathelicidins LL-37 and BMAP28 and defensin hBD-2, as well as the synthetic IDR peptides IDR-1 and IDR-1002, can modulate host immune responses for the resolution of pathogen-induced inflammation $[10,11,31-33]$. In a recent study, we also demonstrated that IDR-1002 can suppress immune-mediated inflammation under conditions that contribute to tissue destruction in inflammatory arthritis [20]. The anti-inflammatory activity of these cationic peptides appears to be targeted and selective. HDPs such as LL-37 and hBD-3 have been demonstrated to target inflammatory pathways such as Toll-like receptor to NF- $\mathrm{KB}$ in the presence of exogenous inflammatory stimuli, resulting in selective suppression of pro-inflammatory responses, while maintaining or enhancing critical immune responses such as cell recruitment and movement and crucial anti-inflam- 


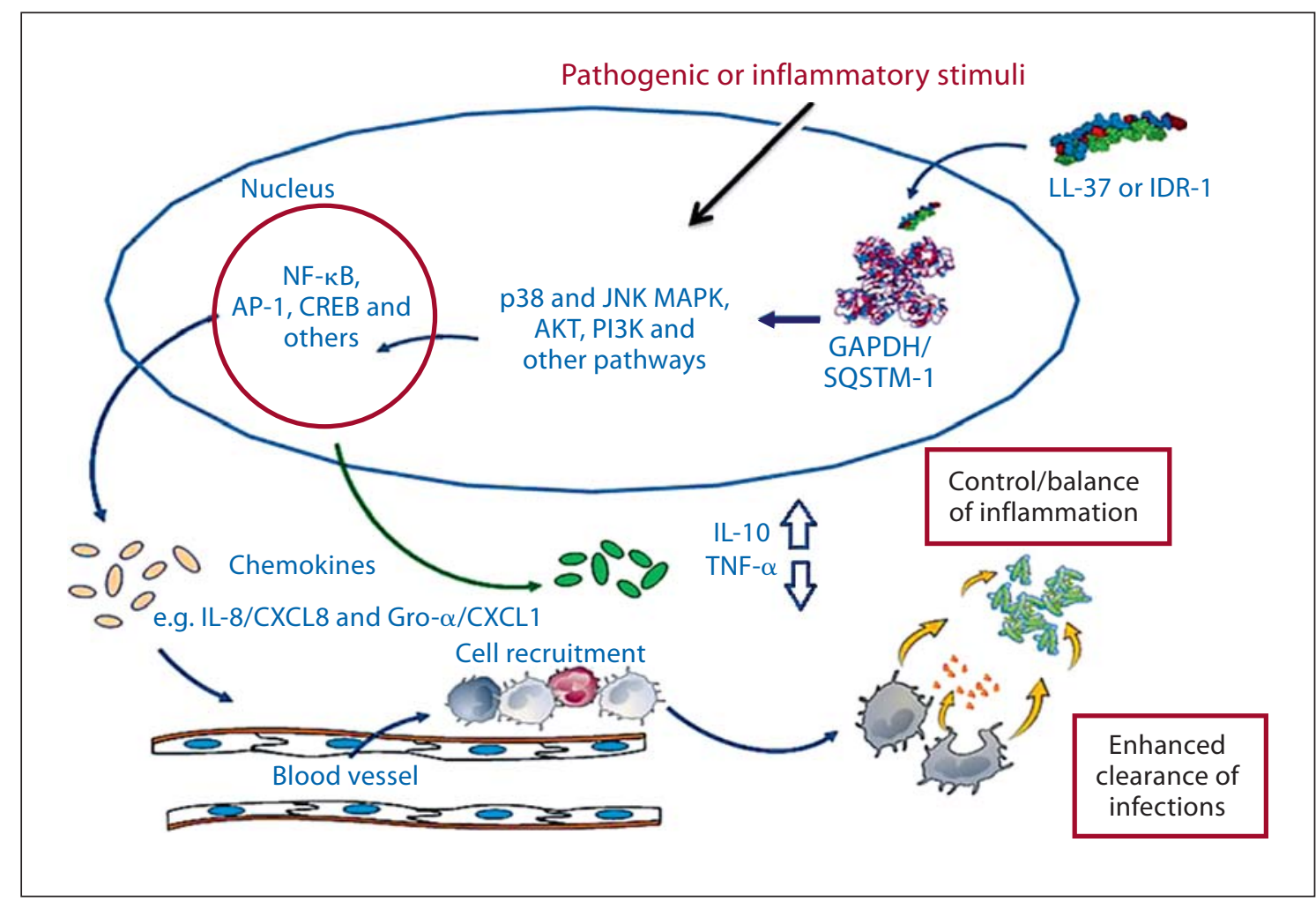

Fig. 1. Mechanism of immunomodulatory activity of LL-37 and IDR-1. Intracellular uptake of LL-37 and IDR1 is hypothesized to be mediated by an atypical endocytic process. Interaction of these peptides with intracellular receptors such as GAPDH and sequestosome (SQSTM)-1 facilitates alteration of pathogen- or inflammatory mediator-induced signalling pathways, leading to alteration of transcription factor activity with different kinetics. The overall downstream effect is selective control of inflammatory responses and enhanced pathogen clearance. Modified from Mookherjee et al. [35, 40] and Yu et al. [41].

matory mechanisms $[15,34]$. Similar selective anti-inflammatory activity has also been described for the IDR peptides IDR-1 and IDR-1002 [10, 11, 20]. Cathelicidin peptides such as LL-37, BMAP-28 and mimetics IDR-1 and IDR-1002 have been shown to suppress specific proinflammatory responses such as induction of tumour necrosis factor (TNF)- $\alpha$, IL-1 $\beta$, NF- $\kappa B 1$ (p105/p50), TNF$\alpha$-induced protein-2, MMP-3 and nitric oxide in the presence of either pathogenic or immune-mediated inflammatory stimuli, without suppressing production of certain chemokines that are required for cell recruitment and movement. In contrast, these peptides enhance or maintain crucial anti-inflammatory responses such as TNF- $\alpha$-induced protein-3 (also known as A20), the NF$\kappa \mathrm{B}$ inhibitor NFкBIA, expression of IL-10 and the IL-1 antagonist IL-1RA [10, 11, 15, 20, 35-37]. Mechanistic studies to date have demonstrated that the anti-inflammatory or immunomodulatory activity of these peptides is very complex and involves intracellular uptake, endocytic mobilization and interaction with several receptors, resulting in altered signalling pathways (such as NF- $к B$, p38 and JNK MAPK, and PI3K) and transcription factor activities with different kinetics. Intracellular uptake has been shown to be important for the immunomodulatory activity of LL-37 [38], and intracellular uptake was also observed for IDR-1002 [20]. Even though putative cell surface receptors, including Gi-coupled protein receptors, have been described for both LL-37 and IDR-1002 $[11,38,39]$, it is not yet determined whether the intracellular uptake of these peptides is receptor mediated. In addition, intracellular proteins, e.g. GAPDH and sequestosome-1, were demonstrated to be direct interacting protein partners or receptors for the HDP LL-37 and IDR peptide IDR-1, respectively, thus contributing to peptidemediated immune responses $[40,41]$. Taken together, it may be speculated that these peptides interact with mul- 
Table 4. Altered expression of HDPs in immune-mediated inflammatory diseases

\begin{tabular}{|c|c|c|c|}
\hline $\begin{array}{l}\text { Inflammatory } \\
\text { disease }\end{array}$ & Induction & Suppression & $\begin{array}{l}\text { Ref. } \\
\text { No. }\end{array}$ \\
\hline Crohn's disease & - & $\begin{array}{l}\text { hBD-2, hBD-3 } \\
\text { and LL-37 }\end{array}$ & 80 \\
\hline $\begin{array}{l}\text { RA and } \\
\text { osteoarthritis }\end{array}$ & LL-37 and hBD-3 & - & 81 \\
\hline $\begin{array}{l}\text { Systemic lupus } \\
\text { erythematosus }\end{array}$ & LL-37 & - & 82 \\
\hline Asthma & - & hBD-2 & 83 \\
\hline $\begin{array}{l}\text { Chronic obstructive } \\
\text { pulmonary disease }\end{array}$ & hBD-1 & - & 84 \\
\hline $\begin{array}{l}\text { Bronchiolitis oblit- } \\
\text { erans syndrome }\end{array}$ & $\begin{array}{l}\text { hBD-2, HNP-1-3 } \\
\text { and LL-37 }\end{array}$ & - & $\begin{array}{l}85 \\
86\end{array}$ \\
\hline Atopic dermatitis & - & $\begin{array}{l}\text { dermcidin and } \\
\text { LL-37 }\end{array}$ & $\begin{array}{l}87 \\
88\end{array}$ \\
\hline Psoriasis & hBD-2 and LL-37 & - & 43 \\
\hline Rosacea & LL-37 & - & 89 \\
\hline
\end{tabular}

tiple receptors, with the interactions mediating different events dependent on cell type and perhaps the exogenous stimuli. Peptides such as LL-37 and IDR-1 may be taken up by an atypical endocytic pathway, possibly similar to that described for other cationic cell-penetrating peptides $[25,38]$, followed by interaction with intracellular partners such as GAPDH and sequestosome-1, leading to the alteration of immune signalling mechanisms and resulting in the modulation of inflammatory responses in the presence of exogenous inflammatory stimuli (fig. 1). Specific receptor interaction of HDPs and IDR peptides and how this mediates different immune functions is not yet completely resolved. The targeted and selective antiinflammatory activity described for specific HDPs (e.g. LL-37 and BMAP-28) and IDR peptides (IDR-1 and IDR1002) overall results in a net balancing of inflammation and maintains the protective anti-infective responses without excessive harmful inflammation. Therefore, these peptides may prove to be valuable therapeutic agents for controlling the destructive effects of inflammatory diseases without abrogating host defence mechanisms.

\section{Distribution and Potential Application of HDPs in Immune-Mediated Inflammatory Diseases}

Inflammation is an essential element of innate immunity, a breakdown in the regulation of which contributes to progressive tissue and organ damage associated with the pathology of a wide range of chronic inflammatory diseases such as rheumatoid arthritis (RA), asthma, chronic obstructive pulmonary disease, inflammatory bowel disease and atherosclerosis. The etiology and molecular mechanisms of these diverse chronic inflammatory diseases are poorly understood. Altered expression of various HDPs has been reported in immune-mediated chronic inflammatory diseases (summarized in table 4). Human hBD-2 is suppressed in Crohn's disease and allergic airway inflammation but found to be elevated in psoriasis (table 4). Likewise, cathelicidin LL-37 is suppressed in Crohn's and atopic dermatitis but elevated in systemic lupus erythematosus (SLE) and RA (table 4). A recent study has also demonstrated that patients with SLE develop autoantibodies to LL-37 and proposed that LL37-self DNA complex is crucial in the chronic activation of plasmacytoid dendritic cells central to the pathogenesis of SLE [42]. Aggregates of LL-37 and extracellular selfDNA fragments have been shown to be taken up by plasmacytoid dendritic cells, triggering a robust interferon response [43]. These studies indicate that dysregulation of certain HDPs may be linked to the pathology of chronic inflammatory diseases.

A common element associated with chronic inflammatory diseases is the dysregulation of the cytokine and chemokine balance. Several critical pro-inflammatory cytokines are elevated in chronic inflammatory diseases such as TNF- $\alpha$, IL-1 $\beta$, IL-15 and IL-23. Therefore, current therapeutic strategies for these diseases include targeting inflammatory cytokines such as TNF- $\alpha$ [44]. However, these current therapies often result in an increased risk of infections, including reactivation of tuberculosis, and the potential for development of cancers due to comprehensive immune suppression [45]. Therefore, there is a need to explore alternate therapeutic strategies, ideally a therapy that can suppress the elevated inflammatory responses without neutralizing immune mediators required for the resolution of infections and neoplasms. As discussed above, certain HDPs and IDR peptides can selectively regulate the inflammatory process while maintaining responses required for the resolution of infections. The ability of these peptides to result in a net balancing of inflammation, without compromising host immunity required for resolution of infections, makes them attractive 
candidates as potential therapeutics for controlling the destructive effects of the inflammatory processes in immune-mediated chronic inflammatory diseases.

Recent studies have demonstrated that some HDPs and IDR peptides can alter immune-mediated cellular responses. For example, human cathelicidin LL-37 differentially alters cytokine-induced responses in blood-derived mononuclear cells, synergistically enhances certain responses induced by IL-1 $\beta$ and GM-CSF [46] and, in contrast, suppresses the interferon- $\boldsymbol{\gamma}$-induced cellular response which is critical in Th1-polarized immune responses [47]. The duality of the pro- and anti-inflammatory properties of LL-37 was also demonstrated in psoriasis, which is a Th1-mediated inflammatory autoimmune disease, and it was hypothesized that LL-37-related peptides can act both as regulators and effectors in psoriasis [48]. In addition, a recent study has shown that LL-37 can interfere in the activation of AIM2 inflammasome, IL-1 $\beta$ production and autoimmune inflammation in psoriasis [49]. Based on these studies, it can thus be speculated that these HDPs or their synthetic IDR derivatives may be beneficial for the development of therapeutics for chronic inflammatory diseases, perhaps with a bias toward Th1-polarized chronic inflammatory diseases, which could also be peptide dependent. Consistent with this, the cathelicidin HDP rCRAMP was shown to heal gastric ulcers in an animal model of colitis [50]. Similarly, we have recently demonstrated that a 12-amino-acid cationic IDR peptide, IDR-1002, designed from a bovine cathelicidin, can indeed selectively limit immune-mediated pro-inflammatory responses, under conditions such as those that contribute to tissue destruction in RA [20], which is also largely a Th1-polarized autoimmune inflammatory disease. The IDR-1002 peptide exhibits a targeted and distinct immunomodulatory activity on both immune cells, e.g. macrophages and neutrophils (demonstrated both in vitro and in in vivo studies) [11], and stromal cells, e.g. human fibroblast-like synoviocytes [20]. In addition to the early proof-of-concept studies discussed above, a cationic peptide therapeutic, Omiganan (Migenix Pharmaceuticals), has been demonstrated to be effective against rosacea in phase II clinical trials. Even though investigating the use of HDPs and their synthetic IDR derivatives for controlling the destructive effects of sustained inflammation in chronic inflammatory diseases is in its infancy, these early studies have shown promise and therefore warrant further exploration. However, there are multiple challenges associated with the development of cationic peptide therapeutics. The first involves bioavailability. Cationic peptides are

Immunomodulatory Host Defence

Peptides potentially vulnerable to proteases, for example trypsinlike enzymes that have a propensity for basic residues, which is a characteristic feature of cationic HDPs. Several studies have provided solutions to circumvent this problem, such as the use of D-amino acids, chemical modifications of the cationic peptides to make them protease resistant, use of a non-peptide backbone and formulations using liposomes to mask the peptides [51]. Secondly, there is the issue of potential toxicity; however, it appears that small IDR peptides designed from natural HDPs have significantly lower toxicity [10]. There is a lack of pharmacokinetic or toxicology data for cationic peptides, and this is essential for further development of these peptides as therapeutics. The third challenge is the cost of goods, as the cost of manufacturing synthetic peptides is significantly high. Exploring new methods for producing recombinant cationic peptides and designing smaller bioactive IDR peptides may be effective in lowering the cost for cationic peptide therapeutics. Overall, the development of cationic peptide therapeutics is focused on designing small IDR peptides, based conceptually on HDPs, with optimized bioactivity and lower cytotoxicity.

\section{Summary}

HDPs are widely distributed natural molecules that play a critical role in anti-infective immunity. Research in the last decade has demonstrated that the biological roles of natural HDPs are very diverse and influence multiple aspects of immunity. It is now well appreciated that the mechanism of the multifaceted role of HDPs in immunity is complex, involving various signalling pathways, and is often determined by physiological conditions, the cellular environment and the extracellular milieu. Specific interacting cellular partners or receptors for various HDPs or IDR peptides, the process of endocytic uptake of the peptides and how this mediates diverse immune functions need to be completely resolved. Moreover, there is limited understanding of the structure and immunomodulatory activity relationship for these peptides. Nevertheless, the paradoxical effect of certain HDPs in enhancing innate immune responses to control infections and at the same time their ability to control inflammation makes these peptides attractive candidates for both anti-infective and anti-inflammatory therapeutics. The multifaceted roles of HDPs and their synthetic mimics, i.e. IDR peptides, have resulted in research into their use as antimicrobials, anti-inflammatory agents and adjuvants and in wound healing. However, there are 
some challenges in the development of cationic peptide therapeutics, including limited bioavailability, associated toxicity and high manufacturing costs. Overall, cationic HDPs and IDR peptides represent an exciting avenue in immunomodulatory therapeutics, which, although still in its infancy, warrants further exploration.

\section{Disclosure Statement}

N.M. is supported by the Health Sciences Centre Foundation (Manitoba, Canada) and the Manitoba Health Research Council for peptide research.

\section{References}

$\checkmark 1$ Cederlund A, Gudmundsson GH, Agerberth B: Antimicrobial peptides important in innate immunity. FEBS J 2011;278:39423951.

- 2 Tossi A, Sandri L: Molecular diversity in gene-encoded, cationic antimicrobial polypeptides. Curr Pharm Des 2002;8:743-761.

3 Guani-Guerra E, Santos-Mendoza T, LugoReyes SO, Teran LM: Antimicrobial peptides: general overview and clinical implications in human health and disease. Clin Immunol 2010;135:1-11.

\4 Molhoek EM, van Dijk A, Veldhuizen EJ, Haagsman HP, Bikker FJ: A cathelicidin-2derived peptide effectively impairs Staphylococcus epidermidis biofilms. Int J Antimicrob Agents 2011;37:476-479.

5 Rajanbabu V, Chen JY: Antiviral function of tilapia hepcidin 1-5 and its modulation of immune-related gene expressions against infectious pancreatic necrosis virus (IPNV) in Chinook salmon embryo (CHSE)-214 cells. Fish Shellfish Immunol 2011;30:39-44.

-6 Bowdish DM, Davidson DJ, Lau YE, Lee K, Scott MG, Hancock RE: Impact of LL-37 on anti-infective immunity. J Leukoc Biol 2005; 77:451-459.

7 Arnett E, Lehrer RI, Pratikhya P, Lu W, Seveau S: Defensins enable macrophages to inhibit the intracellular proliferation of Listeria monocytogenes. Cell Microbiol 2011;13: 635-651.

-8 Haines LR, Hancock RE, Pearson TW: Cationic antimicrobial peptide killing of African trypanosomes and Sodalis glossinidius, a bacterial symbiont of the insect vector of sleeping sickness. Vector Borne Zoonotic Dis 2003;3:175-186.

-9 Bals R, Wang X, Wu Z, Freeman T, Bafna V, Zasloff M, Wilson JM: Human beta-defensin 2 is a salt-sensitive peptide antibiotic expressed in human lung. J Clin Invest 1998; 102:874-880.

-10 Scott MG, Dullaghan E, Mookherjee N, Glavas N, Waldbrook M, Thompson A, Wang A, Lee K, Doria S, Hamill P, Yu JJ, Li Y, Donini O, Guarna MM, Finlay BB, North JR, Hancock RE: An anti-infective peptide that selectively modulates the innate immune response. Nat Biotechnol 2007;25: 465-472.

-11 Nijnik A, Madera L, Ma S, Waldbrook M, Elliott MR, Easton DM, Mayer ML, Mullaly SC, Kindrachuk J, Jenssen H, Hancock RE:
Synthetic cationic peptide IDR-1002 provides protection against bacterial infections through chemokine induction and enhanced leukocyte recruitment. J Immunol 2010;184: 2539-2550.

12 Bevins CL, Salzman NH: Paneth cells, antimicrobial peptides and maintenance of intestinal homeostasis. Nat Rev Microbiol 2011;9:356-368.

13 Gallo RL: Sounding the alarm: multiple functions of host defense peptides. J Invest Dermatol 2008;128:5-6.

14 Allaker RP: Host defence peptides - a bridge between the innate and adaptive immune responses. Trans R Soc Trop Med Hyg 2008; 102:3-4.

15 Mookherjee N, Brown KL, Bowdish DM, Doria S, Falsafi R, Hokamp K, Roche FM, Mu R, Doho GH, Pistolic J, Powers JP, Bryan J, Brinkman FS, Hancock RE: Modulation of the TLR-mediated inflammatory response by the endogenous human host defense peptide LL-37. J Immunol 2006;176: 2455-2464.

16 Diamond G, Beckloff N, Weinberg A, Kisich $\mathrm{KO}$ : The roles of antimicrobial peptides in innate host defense. Curr Pharm Des 2009; 15:2377-2392.

17 Hosokawa I, Hosokawa Y, Komatsuzawa H, Goncalves RB, Karimbux N, Napimoga MH, Seki M, Ouhara K, Sugai M, Taubman MA, Kawai T: Innate immune peptide LL-37 displays distinct expression pattern from betadefensins in inflamed gingival tissue. Clin Exp Immunol 2006;146:218-225.

18 Jo EK: Innate immunity to mycobacteria: vitamin D and autophagy. Cell Microbiol 2010; 12:1026-1035.

19 Hilpert K, Elliott MR, Volkmer-Engert R, Henklein P, Donini O, Zhou Q, Winkler DF, Hancock RE: Sequence requirements and an optimization strategy for short antimicrobial peptides. Chem Biol 2006;13: 1101-1107.

20 Turner-Brannen E, Choi KY, Lippert DN, Cortens JP, Hancock RE, El-Gabalawy H, Mookherjee N: Modulation of interleukin$1 \beta$-induced inflammatory responses by a synthetic cationic innate defence regulator peptide, IDR-1002, in synovial fibroblasts. Arthritis Res Ther 2011;13:R129.

21 Wieczorek M, Jenssen H, Kindrachuk J, Scott WR, Elliott M, Hilpert K, Cheng JT, Hancock RE, Straus SK: Structural studies of a peptide with immune modulating and direct antimicrobial activity. Chem Biol 2010; 17:970-980.

22 Scott MG, Davidson DJ, Gold MR, Bowdish D, Hancock R: The human antimicrobial peptide LL-37 is a multifunctional modulator of innate immune responses. J Immunol 2002;169:3883-3891

-23 Yang D, Chertov O, Bykovskaia SN, Chen Q, Buffo MJ, Shogan J, Anderson M, Schroder JM, Wang JM, Howard OM, Oppenheim JJ: Beta-defensins: linking innate and adaptive immunity through dendritic and $\mathrm{T}$ cell CCR6. Science 1999;286:525-528.

24 Nagaoka I, Tamura H, Hirata M: An antimicrobial cathelicidin peptide, human CAP18/ LL-37, suppresses neutrophil apoptosis via the activation of formyl-peptide receptorlike 1 and P2X7. J Immunol 2006; 176:30443052.

25 Bandholtz L, Ekman GJ, Vilhelmsson M, Buentke E, Agerberth B, Scheynius A, Gudmundsson GH: Antimicrobial peptide LL-37 internalized by immature human dendritic cells alters their phenotype. Scand J Immunol 2006;63:410-419.

26 Davidson DJ, Currie AJ, Reid GS, Bowdish DM, MacDonald KL, Ma RC, Hancock RE, Speert DP: The cationic antimicrobial peptide LL-37 modulates dendritic cell differentiation and dendritic cell-induced T cell polarization. J Immunol 2004;172:1146-1156.

27 Funderburg N, Lederman MM, Feng Z, Drage MG, Jadlowsky J, Harding CV, Weinberg A, Sieg SF: Human-defensin-3 activates professional antigen-presenting cells via toll-like receptors 1 and 2. Proc Natl Acad Sci USA 2007;104:18631-18635.

28 Rodriguez-Garcia M, Oliva H, Climent N, Escribese MM, Garcia F, Moran TM, Gatell JM, Gallart T: Impact of alpha-defensins13 on the maturation and differentiation of human monocyte-derived DCs. Concentration-dependent opposite dual effects. Clin Immunol 2009;131:374-384.

29 Kin NW, Chen Y, Stefanov EK, Gallo RL, Kearney JF: Cathelin-related antimicrobial peptide differentially regulates $\mathrm{T}$ - and $\mathrm{B}$-cell function. Eur J Immunol 2011;41:3006-3016.

- 30 Lillard JW Jr, Boyaka PN, Chertov O, Oppenheim JJ, McGhee JR: Mechanisms for induction of acquired host immunity by neutrophil peptide defensins. Proc Natl Acad Sci USA 1999;96:651-656. 
- 31 Cirioni O, Giacometti A, Ghiselli R, Bergnach C, Orlando F, Silvestri C, Mocchegiani F, Licci A, Skerlavaj B, Rocchi M, Saba V, Zanetti M, Scalise G: LL-37 protects rats against lethal sepsis caused by gram-negative bacteria. Antimicrob Agents Chemother 2006;50:1672-1679.

32 Giacometti A, Cirioni O, Ghiselli R, Bergnach C, Orlando F, D'Amato G, Mocchegiani F, Silvestri C, Del Prete MS, Skerlavaj B, Saba V, Zanetti M, Scalise G: The antimicrobial peptide BMAP-28 reduces lethality in mouse models of staphylococcal sepsis. Crit Care Med 2004;32:2485-2490.

-33 Shu Q, Shi Z, Zhao Z, Chen Z, Yao H, Chen Q, Hoeft A, Stuber F, Fang X: Protection against Pseudomonas aeruginosa pneumonia and sepsis-induced lung injury by overexpression of beta-defensin-2 in rats. Shock 2006;26:365-371.

- 34 Semple F, Macpherson H, Webb S, Cox SL, Mallin LJ, Tyrrell C, Grimes GR, Semple CA, Nix MA, Millhauser GL, Dorin JR: Human $\beta$ defensin 3 affects the activity of pro-inflammatory pathways associated with MyD88 and TRIF. Eur J Immunol 2011;41:3291-3300.

- 35 Mookherjee N, Hamill P, Gardy J, Blimkie D, Falsafi R, Chikatamarla A, Arenillas DJ, Doria S, Kollmann TR, Hancock RE: Systems biology evaluation of immune responses induced by human host defence peptide LL-37 in mononuclear cells. Mol Biosyst 2009;5:483-496.

- 36 Brown KL, Poon GF, Birkenhead D, Pena OM, Falsafi R, Dahlgren C, Karlsson A, Bylund J, Hancock RE, Johnson P: Host defense peptide LL-37 selectively reduces proinflammatory macrophage responses. J Immunol 2011;186:5497-5505.

- 37 Mookherjee N, Wilson HL, Doria S, Popowych Y, Falsafi R, Yu JJ, Li Y, Veatch S, Roche FM, Brown KL, Brinkman FS, Hokamp K, Potter A, Babiuk LA, Griebel PJ, Hancock RE: Bovine and human cathelicidin cationic host defense peptides similarly suppress transcriptional responses to bacterial lipopolysaccharide. J Leukoc Biol 2006; 80:1563-1574.

- 38 Lau YE, Rozek A, Scott MG, Goosney DL, Davidson DJ, Hancock RE: Interaction and cellular localization of the human host defense peptide LL-37 with lung epithelial cells. Infect Immun 2005;73:583-591.

-39 De Y, Chen Q, Schmidt AP, Anderson GM, Wang JM, Wooters J, Oppenheim JJ, Chertov O: LL-37, the neutrophil granule- and epithelial cell-derived cathelicidin, utilizes formyl peptide receptor-like 1 (FPRL1) as a receptor to chemoattract human peripheral blood neutrophils, monocytes, and T cells. J Exp Med 2000;192:1069-1074.

-40 Mookherjee N, Lippert DN, Hamill P, Falsafi R, Nijnik A, Kindrachuk J, Pistolic J, Gardy J, Miri P, Naseer M, Foster LJ, Hancock RE: Intracellular receptor for human host defense peptide LL-37 in monocytes. J Immunol 2009;183:2688-2696.
41 Yu HB, Kielczewska A, Rozek A, Takenaka S, Li Y, Thorson L, Hancock RE, Guarna MM, North JR, Foster LJ, Donini O, Finlay BB: Sequestosome-1/p62 is the key intracellular target of innate defense regulator peptide. J Biol Chem 2009;284:36007-36011.

42 Lande R, Ganguly D, Facchinetti V, Frasca L, Conrad C, Gregorio J, Meller S, Chamilos G, Sebasigari R, Riccieri V, Bassett R, Amuro H, Fukuhara S, Ito T, Liu YJ, Gilliet M: Neutrophils activate plasmacytoid dendritic cells by releasing self-DNA-peptide complexes in systemic lupus erythematosus. Sci Transl Med 2011;3:73ra19.

43 Gilliet M, Lande R: Antimicrobial peptides and self-DNA in autoimmune skin inflammation. Curr Opin Immunol 2008;20:401-407.

-44 Feldmann M, Maini RN: Lasker Clinical Medical Research Award. TNF defined as a therapeutic target for rheumatoid arthritis and other autoimmune diseases. Nat Med 2003;9:1245-1250.

45 Botsios C: Safety of tumour necrosis factor and interleukin-1 blocking agents in rheumatic diseases. Autoimmun Rev 2005;4:162170.

46 Yu J, Mookherjee N, Wee K, Bowdish DM, Pistolic J, Li Y, Rehaume L, Hancock RE: Host defense peptide LL-37, in synergy with inflammatory mediator IL-1beta, augments immune responses by multiple pathways. J Immunol 2007;179:7684-7691.

47 Nijnik A, Pistolic J, Wyatt A, Tam S, Hancock RE: Human cathelicidin peptide LL-37 modulates the effects of IFN-gamma on APCs. J Immunol 2009;183:5788-5798.

48 Kanda N, Ishikawa T, Kamata M, Tada Y, Watanabe S: Increased serum leucine, leucine-37 levels in psoriasis: positive and negative feedback loops of leucine, leucine-37 and pro- or anti-inflammatory cytokines. Hum Immunol 2010;71:1161-1171.

49 Dombrowski Y, Peric M, Koglin S, Kammerbauer C, Goss C, Anz D, Simanski M, Glaser R, Harder J, Hornung V, Gallo RL, Ruzicka T, Besch R, Schauber J: Cytosolic DNA triggers inflammasome activation in keratinocytes in psoriatic lesions. Sci Transl Med 2011;3:82ra38.

50 Yang YH, Wu WK, Tai EK, Wong HP, Lam EK, So WH, Shin VY, Cho CH: The cationic host defense peptide rCRAMP promotes gastric ulcer healing in rats. J Pharmacol Exp Ther 2006;318:547-554.

51 Hadley EB, Hancock RE: Strategies for the discovery and advancement of novel cationic antimicrobial peptides. Curr Top Med Chem 2010;10:1872-1881.

52 Soehnlein O, Zernecke A, Eriksson EE, Rothfuchs AG, Pham CT, Herwald H, Bidzhekov K, Rottenberg ME, Weber C, Lindbom L: Neutrophil secretion products pave the way for inflammatory monocytes. Blood 2008;112:1461-1471.
3 Tjabringa GS, Ninaber DK, Drijfhout JW, Rabe KF, Hiemstra PS: Human cathelicidin 1l-37 is a chemoattractant for eosinophils and neutrophils that acts via formyl-peptide receptors. Int Arch Allergy Immunol 2006; 140:103-112.

54 Yang D, Chen Q, Chertov O, Oppenheim JJ: Human neutrophil defensins selectively chemoattract naive $t$ and immature dendritic cells. J Leukoc Biol 2000;68:9-14.

55 Territo MC, Ganz T, Selsted ME, Lehrer R: Monocyte-chemotactic activity of defensins from human neutrophils. J Clin Invest 1989; 84:2017-2020.

56 Huang HJ, Ross CR, Blecha F: Chemoattractant properties of pr-39, a neutrophil antibacterial peptide. J Leukoc Biol 1997;61:624629.

57 Ghosh SK, Gupta S, Jiang B, Weinberg A: Fusobacterium nucleatum and human beta defensins modulate the release of antimicrobial chemokine ccl20/mip-3\{alpha\}. Infect Immun 2011;79:4578-4587.

58 Montreekachon P, Chotjumlong P, Bolscher JG, Nazmi K, Reutrakul V, Krisanaprakornkit S: Involvement of $\mathrm{p} 2 \mathrm{x}(7)$ purinergic receptor and mek1/2 in interleukin- 8 upregulation by ll-37 in human gingival fibroblasts. J Periodontal Res 2011;46:327-337.

59 Bowdish DM, Davidson DJ, Hancock RE: Immunomodulatory properties of defensins and cathelicidins. Curr Top Microbiol Immunol 2006;306:27-66.

60 Nagaoka I, Niyonsaba F, Tsutsumi-Ishii Y, Tamura H, Hirata M: Evaluation of the effect of human beta-defensins on neutrophil apoptosis. Int Immunol 2008;20:543-553.

-61 Niyonsaba F, Ushio H, Hara M, Yokoi H, Tominaga M, Takamori K, Kajiwara N, Saito H, Nagaoka I, Ogawa H, Okumura K: Antimicrobial peptides human beta-defensins and cathelicidin 1l-37 induce the secretion of a pruritogenic cytokine il-31 by human mast cells. J Immunol 2010;184:3526-3534.

62 Bowdish DM, Davidson DJ, Speert DP, Hancock RE: The human cationic peptide ll-37 induces activation of the extracellular signal-regulated kinase and p38 kinase pathways in primary human monocytes. J Immunol 2004;172:3758-3765.

63 Tjabringa GS, Aarbiou J, Ninaber DK, Drijfhout JW, Sorensen OE, Borregaard N, Rabe KF, Hiemstra PS: The antimicrobial peptide 1l-37 activates innate immunity at the airway epithelial surface by transactivation of the epidermal growth factor receptor. J Immunol 2003;171:6690-6696.

64 Soehnlein O, Kai-Larsen Y, Frithiof R, Sorensen OE, Kenne E, Scharffetter-Kochanek $\mathrm{K}$, Eriksson EE, Herwald H, Agerberth B, Lindbom L: Neutrophil primary granule proteins hbp and hnpl-3 boost bacterial phagocytosis by human and murine macrophages. J Clin Invest 2008;118:3491-3502. 
65 Soehnlein O, Wantha S, Simsekyilmaz S, Doring Y, Megens RT, Mause SF, Drechsler M, Smeets R, Weinandy S, Schreiber F, Gries T, Jockenhoevel S, Moller M, Vijayan S, van Zandvoort MA, Agerberth B, Pham CT, Gallo RL, Hackeng TM, Liehn EA, Zernecke A, Klee D, Weber C: Neutrophil-derived cathelicidin protects from neointimal hyperplasia. Sci Transl Med 2011;3:103ra198.

- 66 Steinstraesser L, Koehler T, Jacobsen F, Daigeler A, Goertz O, Langer S, Kesting M, Steinau H, Eriksson E, Hirsch T: Host defense peptides in wound healing. Mol Med 2008; 14:528-537.

- 67 Koczulla R, von Degenfeld G, Kupatt C, Krotz F, Zahler S, Gloe T, Issbrucker K, Unterberger P, Zaiou M, Lebherz C, Karl A, Raake P, Pfosser A, Boekstegers P, Welsch U, Hiemstra PS, Vogelmeier C, Gallo RL, Clauss M, Bals R: An angiogenic role for the human peptide antibiotic 1l-37/hcap-18. J Clin Invest 2003;111:1665-1672.

68 Li J, Post M, Volk R, Gao Y, Li M, Metais C, Sato K, Tsai J, Aird W, Rosenberg RD, Hampton TG, Sellke F, Carmeliet P, Simons M: $\operatorname{Pr} 39$, a peptide regulator of angiogenesis. Nat Med 2000;6:49-55.

-69 Niyonsaba F, Someya A, Hirata M, Ogawa H, Nagaoka I: Evaluation of the effects of peptide antibiotics human beta-defensins-1/-2 and 11-37 on histamine release and prostaglandin d(2) production from mast cells. Eur J Immunol 2001;31:1066-1075.

70 van der Merwe J, Prysliak T, Gerdts V, PerezCasal J: Protein chimeras containing the mycoplasma bovis gapdh protein and bovine host-defence peptides retain the properties of the individual components. Microb Pathog 2011;50:269-277.

-71 Cao D, Li H, Jiang Z, Cheng Q, Yang Z, Xu C, Cao G, Zhang L: Cpg oligodeoxynucleotide synergizes innate defense regulator peptide for enhancing the systemic and mucosal immune responses to pseudorabies attenuated virus vaccine in piglets in vivo. Int Immunopharmacol 2011;11:748-754.

72 Scruten E, Kovacs-Nolan J, Griebel PJ, Latimer L, Kindrachuk J, Potter A, Babiuk LA, Littel-van den Hurk SD, Napper S: Retro-inversion enhances the adjuvant and cpg co-adjuvant activity of host defence peptide bac2a. Vaccine 2010;28:2945-2956.
73 Torossian A, Gurschi E, Bals R, Vassiliou T, Wulf HF, Bauhofer A: Effects of the antimicrobial peptide ll-37 and hyperthermic preconditioning in septic rats. Anesthesiology 2007;107:437-441.

74 Jeng L, Yamshchikov AV, Judd SE, Blumberg HM, Martin GS, Ziegler TR, Tangpricha V: Alterations in vitamin d status and anti-microbial peptide levels in patients in the intensive care unit with sepsis. J Transl Med 2009; $7: 28$.

75 Mandic Havelka A, Yektaei-Karin E, Hultenby K, Sorensen OE, Lundahl J, Berggren V, Marchini G: Maternal plasma level of antimicrobial peptide 1137 is a major determinant factor of neonatal plasma 1137 level. Acta Paediatr 2010;99:836-841.

76 Starner TD, Agerberth B, Gudmundsson GH, McCray PB, Jr.: Expression and activity of beta-defensins and 11-37 in the developing human lung. J Immunol 2005;174:16081615.

77 Dale BA, Tao R, Kimball JR, Jurevic RJ: Oral antimicrobial peptides and biological control of caries. BMC Oral Health 2006;6 (Suppl 1):S13.

78 Mukae H, Iiboshi $\mathrm{H}$, Nakazato M, Hiratsuka T, Tokojima M, Abe K, Ashitani J, Kadota J, Matsukura S, Kohno S: Raised plasma concentrations of alpha-defensins in patients with idiopathic pulmonary fibrosis. Thorax 2002;57:623-628.

-79 Kindrachuk J, Jenssen $H$, Elliott $M$, Townsend R, Nijnik A, Lee SF, Gerdts V, Babiuk LA, Halperin SA, Hancock RE: A novel vaccine adjuvant comprised of a synthetic innate defence regulator peptide and cpg oligonucleotide links innate and adaptive immunity. Vaccine 2009;27:4662-4671.

80 Wehkamp J, Schmid M, Stange EF: Defensins and other antimicrobial peptides in inflammatory bowel disease. Curr Opin Gastroenterol 2007;23:370-378.
81 Paulsen F, Pufe T, Conradi L, Varoga D, Tsokos M, Papendieck J, Petersen W: Antimicrobial peptides are expressed and produced in healthy and inflamed human synovial membranes. J Pathol 2002;198:369-377.

82 Sun CL, Zhang FZ, Li P, Bi LQ: Ll-37 expression in the skin in systemic lupus erythematosus. Lupus 2011;20:904-911.

-83 Beisswenger C, Kandler K, Hess C, Garn H, Felgentreff K, Wegmann M, Renz H, Vogelmeier C, Bals R: Allergic airway inflammation inhibits pulmonary antibacterial host defense. J Immunol 2006;177:1833-1837.

84 Andresen E, Gunther G, Bullwinkel J, Lange $\mathrm{C}$, Heine $\mathrm{H}$ : Increased expression of beta-defensin 1 (defb1) in chronic obstructive pulmonary disease. PLoS One 2011;6:e21898.

85 Anderson RL, Hiemstra PS, Ward C, Forrest IA, Murphy D, Proud D, Lordan J, Corris PA, Fisher AJ: Antimicrobial peptides in lung transplant recipients with bronchiolitis obliterans syndrome. Eur Respir J 2008;32:670677.

86 Ross DJ, Cole AM, Yoshioka D, Park AK, Belperio JA, Laks H, Strieter RM, Lynch JP, 3rd, Kubak B, Ardehali A, Ganz T: Increased bronchoalveolar lavage human beta-defensin type 2 in bronchiolitis obliterans syndrome after lung transplantation. Transplantation 2004;78:1222-1224.

$>87$ Rieg S, Steffen H, Seeber S, Humeny A, Kalbacher H, Dietz K, Garbe C, Schittek B: Deficiency of dermcidin-derived antimicrobial peptides in sweat of patients with atopic dermatitis correlates with an impaired innate defense of human skin in vivo. J Immunol 2005;174:8003-8010.

88 Ong PY, Ohtake T, Brandt C, Strickland I, Boguniewicz M, Ganz T, Gallo RL, Leung DY: Endogenous antimicrobial peptides and skin infections in atopic dermatitis. $\mathrm{N} \mathrm{Engl} \mathrm{J}$ Med 2002;347:1151-1160.

- 89 Yamasaki K, Di Nardo A, Bardan A, Murakami $\mathrm{M}$, Ohtake $\mathrm{T}$, Coda $\mathrm{A}$, Dorschner RA, Bonnart C, Descargues P, Hovnanian A, Morhenn VB, Gallo RL: Increased serine protease activity and cathelicidin promotes skin inflammation in rosacea. Nat Med 2007;13:975-980. 